\title{
Maria Sylvia Nunes: memórias, ensino e práticas teatrais em Belém do Pará
}

\author{
Maria Sylvia Nunes: Memories, teaching \\ and theatrical practices in Belém do Pará
}

Entrevista com Maria Sylvia Nunes concedida a Denis Bezerra ${ }^{1}$ e Karine Jansen ${ }^{2}$ 


\section{Resumo}

A presente entrevista, realizada com a professora e diretora teatral Maria Sylvia Nunes, é um importante registro sobre as práticas do teatro amador paraense/brasileiro das décadas de 50 e 60 do século XX. Ela fez parte da pesquisa de doutoramento de Denis Bezerra (2016). A entrevista partiu de três eixos: 01 - história de vida (família, formação educacional); 2 - memórias do espaço urbano de Belém (espaços de circulação cultural); 3 - temas diversos sobre teatro paraense (artistas, grupos de teatro, espaços de ensaio e apresentação, dramaturgos, etc.). Suas memórias nos possibilitam perceber como o teatro brasileiro do Norte se organizava e se tornava espaço de fazer, refletir e construir uma sociedade mais humanista.

Palavras-chave: Maria Sylvia Nunes; teatro amador; formação humanista

\section{Abstract}

This interview with teacher and theater director Maria Sylvia Nunes is an important document on the amateur theater production in the Brazilian/ Paraense theater from the fifties and sixties. It was part of Denis Bezerra's PhD research (2016). The interview follows three axes: 1-Life story (family, educational training); 2-Memories from Urban space in Belém (cultural and circulation venues); 3-Miscellaneous themes on Paraense theater (artists, theater groups, rehearsal and performance venues, playwrights, etc.). Her memories allow us to perceive how the Northern Brazilian theater was organized and how it became a space of doing, reflecting and building a more humanistic society.

Keywords: explicit body; female body; performance art; transgression

E-ISSN: 2358.6958

\footnotetext{
1 Prof. Dr. Escola de Teatro e Dança do Instituto de Ciências da Arte da Universidade Federal do Pará (UFPA). Atua no Curso Técnico de Teatro, na Licenciatura em Teatro, e na Pós-graduação em Artes. denisletras@yahoo.com.br

2 Profa. Dra. Escola de Teatro e Dança do Instituto de Ciências da Arte da Universidade Federal do Pará. Atua no Curso Técnico de Teatro e na Licenciatura em Teatro. karinejansendeamorim@gmail.com
} 


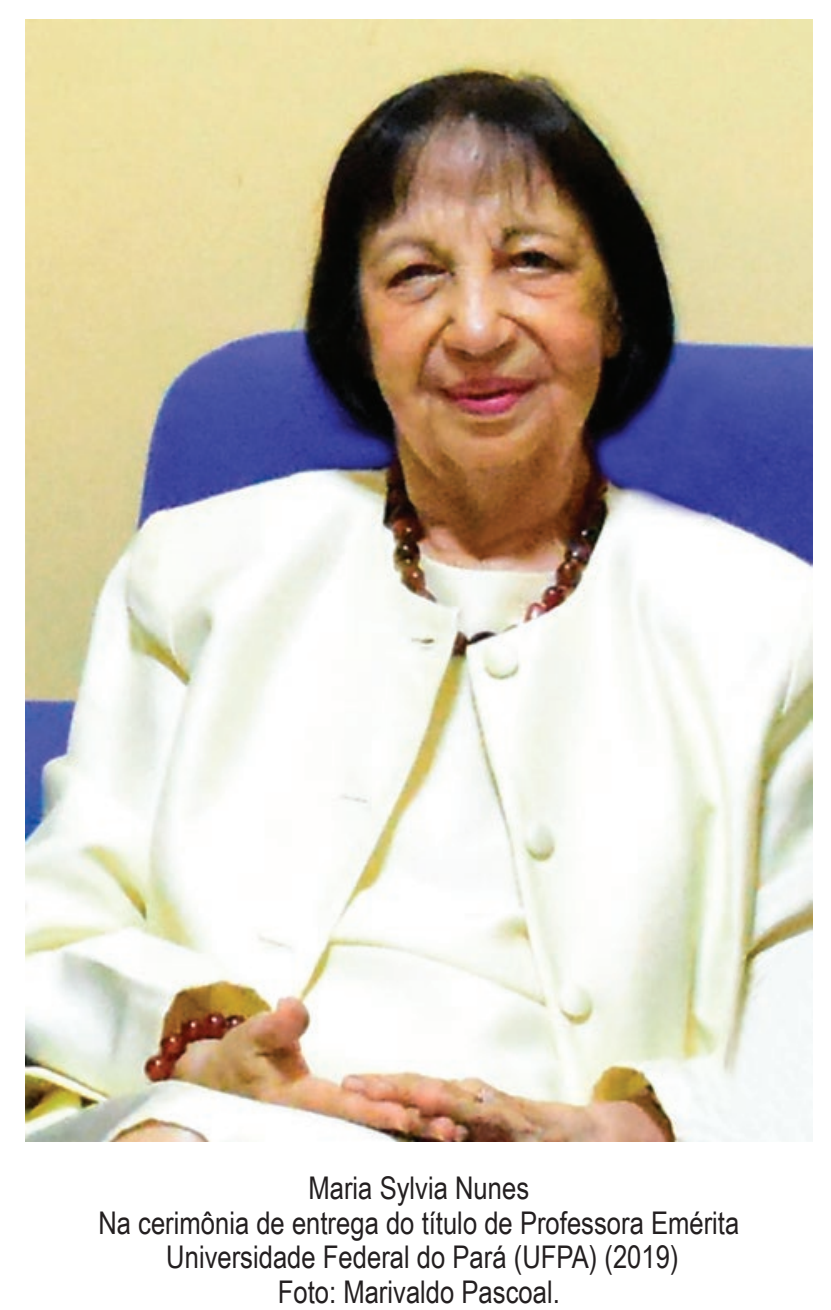

\section{Prólogo}

Em 2019 a Universidade Federal do Pará (UFPA) concedeu o título de Professora Emérita à Maria Sylvia Nunes, a primeira titulação desse tipo para a área das artes na universidade. Com uma trajetória reconhecida nas áreas da produção e do ensino do teatro na Amazônia, ela tem uma contribuição fundamental para a cultura paraense nos últimos 60 anos $^{3}$.

Como diretora teatral, esteve à frente de um importante grupo de teatro amador, Norte Teatro Escola do Pará (1957-1962), o qual participou de importantes festivais nacionais, articulados por Paschoal Carlos Magno. Juntamente com seu esposo, Benedito Nunes, e sua irmã, Angelita Silva, movimentou a cena local e nacional do final dos anos 1950 e início dos 1960.

O Norte Teatro Escola do Pará promoveu espetáculos de vanguarda à época, e ganhou o protagonismo nos Festivais de Teatro Amador e de Estudantes de 1958, em Recife, com a encenação de Morte e Vida Severina do poeta João Cabral de Melo Neto; em 1959, em Santos, com Édipo Rei, de Sófocles, em que Maria Sylvia Nunes ganhou o prêmio de melhor direção teatral nacional. Em ambos os festivais, o ator Carlos Miranda destacou-se e foi premiado como o melhor ator nacional, nos papéis de Severino e Édipo.

3 Regina Maneschy elaborou o Memorial para avaliação da Comissão formada pelo Reitor da UFPA, Prof. Dr. Emmanuel Zagury Tourinho, disponível em: https://ascom.ufpa.br/links/editais/00morialsylvianunes.pdf 
O grupo tinha como norteador de seus trabalhos: encenar textos inéditos nos palcos de Belém e do Brasil, com o objetivo de oferecer às plateias o que eles consideram obras fundamentais para a formação e divulgação de conhecimentos. Dessa maneira, estavam conectados tanto à tradição dramatúrgica, quanto à vanguarda, sempre primando pela qualidade dos textos.

Já como professora, atuou na Escola de Teatro e Dança da UFPA, fundada em 1963, oficialmente. Na época, surgiu como Serviço de Teatro da Universidade do Pará - STUP, que oferecia cursos ligados às artes cênicas, entre eles o seu carro chefe: Curso de Formação de Ator. Dessa maneira, a UFPA foi pioneira na região amazônica ao oferecer o primeiro curso de artes (artes cênicas), hoje a mais antiga, na Amazônia, em funcionamento e a segunda no Brasil, que nasceu no seio universitário.

O embrião do STUP surgiu em maio de 1962 com a oferta de um Curso de Iniciação Teatral, de forma experimental, um acordo estabelecido entre o Reitor da época, José da Silveira Neto, com um coletivo de representantes de alguns grupos de teatro amador de Belém. Para esse primeiro momento da instituição, foram convidados professores de fora do estado, para ajudar aos envolvidos locais na missão de implantar o curso de Formação de Ator na capital paraense: Amir Haddad (Interpretação), Carlos Eugênio Marcondes de Moura (Dicção) e Yolanda Amadei (Expressão Corporal). Juntaram-se a eles os docentes locais: Benedito Nunes (Estética e Psicologia), Maria Sylvia Nunes (História do Espetáculo) e Francisco Paulo Mendes (História e Teoria do Teatro). Como resultado do curso de Iniciação Teatral, no final do ano de 1962, foram apresentados os seguintes espetáculos: O Inglês Maquinista, de Martins Penna; O Delator, de Bertolt Brecht; O Velho da Horta, de Gil Vicente; Caminho Real, de Anton Tchekhov.

Com o aval da Reitoria da universidade, o professor Benedito Nunes, que já era docente da instituição, assumiu a direção geral do STUP e a professora Maria Sylvia Nunes a direção geral dos cursos. Essa unidade acadêmica era formada por: Escola de Teatro, Estúdio de Pesquisas Teatrais e Centro de Estudos Cinematográficos ${ }^{4}$.

Em linhas gerais, Maria Sylvia Nunes ingressou na Universidade Federal do Pará em 1962, onde atuou como docente e gestora do Serviço de Teatro, atual Escola de Teatro e Dança, aposentando-se em 1992, após 30 anos de contribuição com a instituição, no fortalecimento de ações de ensino, pesquisa e extensão ligadas às artes cênicas na Amazônia. Na instituição, dentre tantas funções, trabalhou como: docente (História do Espetáculo); direção escolar; editora de revista acadêmica (Ensaio Geral).

\section{Vamos começar a entrevista perguntando sobre o local e data do seu nascimento.}

Eu nasci em Belém mesmo, agora o local, me parece, foi na Santa Casa, que naquele tempo era o hospital que tinha. Fora isso, tinha a Beneficente, que era dos portugueses, e apesar da minha mãe ser filha de português, ela preferiu ir para Santa Casa. Fala-se na família, eu não sei por que, estava lá, mas não sabia de nada, que nasci às 9h da manhã, então eu sou solar (risos). Eu nasci em 07 de janeiro de 1930. Estou, portanto, com 82 anos, justificando os meus esquecimentos (risos).

4 Sobre os a instalação e os primeiros anos de atividades do STUP, ver Bezerra (2016). 


\section{O primeiro tema da nossa entrevista é a formação escolar e profissão. Como foi a sua formação escolar?}

Olha, o primário foi assim: eu fui primeiro para o jardim da infância no Colégio Ipiranga, que naquele tempo era o colégio que tinha mais ideias e que era considerado, assim, um colégio especial para as crianças. Então eu fui lá. Aí, nos três primeiros dias, eu fiquei um pouco apavorada, porque eu era a última de uma família de quatro mulheres, meu pai era o único homem da casa, e nós éramos criadas numa maior paz desse mundo. Eu cheguei lá, e tinha uns truculentos jogando uns aos outros no chão, eu fiquei apavorada. Quando foi no quarto dia, eu acho, ou quinto, não sei, isso eu estou te dizendo assim, um dos meninos me agarrou que arrancou a minha gola, aí eu cheguei em casa e falei para mamãe: "eu não quero mais ir para aquele lugar, porque as pessoas são estúpidas, mal-educadas". Aí mamãe pensou, pensou que 'se ela for para escola, ela vai ficar com raiva para o resto da vida da escola. Então vamos fazer um contrato: você estuda comigo aqui em casa'.

Parênteses: mamãe era professora antes de casar. Naquele tempo, casava e não trabalhava mais. Então ela parou, mas ela era apaixonada por ensinar a ler, para fazer essas coisas. Mais tarde, eu descobri um artigo dela, na revista do Colégio Paraense, que era onde ela ensinava, falando da educação através da arte. Você imagina. Nesses anos aí, ela era muito para frente. E na estante dela tinha Piaget, tinhas essas coisas todas. Ela lia francês, porque naquele tempo as pessoas tinham francês no curso médio, aprendiam línguas mesmo. Então, a minha mãe disse: 'eu vou te ensinar em casa'. Então assim foi. Eu fiquei estudando com ela, em casa. Era um estudo super light [tranquilo], porque a gente não tinha horário fixo e nada. Assim, de repente, ela tinha uma folga na casa e ela chamava: 'venha cá!' Aí a gente sentava, e conversava, ela me ensinando, e eu já sabia ler, porque eu aprendi com quatro anos. Aí, rapidamente, eu aprendi bastantes coisas. Com sete anos, a mamãe disse: 'agora está na hora, você está grande, mais forte, você já pode resistir aos meninos. Agora você vai para o colégio'. Aí eu fui para o Colégio Moderno.

Quando cheguei lá, eu me matriculei no primeiro ano, mas no meio do ano, a professora me passou para o segundo, porque, quando eu fui para lá, eu já sabia fazer contas, já sabia essas coisas que se chamava ciências naturais, o que eram os três reinos, os três estados. Tudo isso eu já sabia, porque a minha mãe já tinha me ensinado. Então, eu passei para o segundo, no meio do ano, em junho, e no fim do ano eu passei para o terceiro. Aí fiz o primário, assim, num tapa. Graças a minha mãe, que me ensinava em casa. Aí estudei no Colégio Moderno, até sair para faculdade. A vida inteira eu fiquei no Colégio Moderno, porque eu adorava, tive sorte de ter, no primário, professoras maravilhosas, uma das quais foi a Maria Paula Chaves, irmã da Anunciada Chaves, que era uma professora com ideias modernas e... maravilhosa. Olha, ela era tão legal, que tinha um colega nosso, que era inquieto de natureza, para ele ficar sentado era um sacrifício. Então ela deixava nos últimos quinze minutos de aula, ele ficar em pé lá atrás, porque aí ele não atrapalhava nos estudos dos outros, e ele se aliviava daquela tensão de estar obrigado a sentar. Ela era maravilhosa, e entendia as crianças, todo mundo adorava ela, respeitava ela, havia uma maior paz naquela sala de aula. 
Bom, aí eu fiquei no Colégio Moderno, fiz o admissão, naquele tempo se fazia o exame de admissão para entrar no ginasial, como se chamava. E foi aí que eu conheci o Bené [Benedito Nunes]. No dia da prova de admissão, o Bené apareceu, porque ele não era do colégio, ele estudou no colégio das tias dele, aí ele foi fazer o exame. E nós pegamos os primeiros lugares, eu e ele. Aí eu fiquei no colégio... naquele tempo o ensino era maravilhoso. Olha, a gente estudava francês desde o primeiro ano, com dois ou três anos a gente lia perfeitamente francês. Estudávamos latim, a gente conseguia traduzir, porque a gente tinha, também, um professor maravilhoso, que era o Orlando Bitar. Nesse tempo, ele era jovem e até fazia CPOR [Centro de Preparação de Oficiais da Reserva], ele ia, às vezes, para a aula de farda. E ele ensinava de uma maneira, que a gente adorava latim, agora tinha outras matérias que a gente não gostava muito. Por exemplo, eu era péssima em matemática, física e química. Eu era péssima nessas matérias, sabe? Eu só conseguia passar porque tinha uma das matérias de matemática que eu gostava, geometria, porque com geometria você pode, sendo um pouco astuto, descobrir o que é, olhar a figura e daí... Nessa parte de geometria eu me saia bem, mas na álgebra eu me saia péssima. E física eu passava, porque eu tinha uma colega estudiosíssima, meio gênio assim, que ela sabia tudo, matemática, química, física, tudo. Então ela fazia as provas, e nossos professores eram metidinhos a modernos e fazia prova múltipla escolha, então ela fazia assim para mim: segunda, três, para eu marcar a três; primeira, assim... passava colada, porque sinceramente não sabia nada, não sabia nem por onde passava. Eu sabia que tinha um negócio chamado vetores, mas saber o que era (risos), não sabia nada. E química era a mesma coisa, ela me passava cola para eu poder passar.

\section{Aí a senhora foi para faculdade?}

Aí eu fui para faculdade. Na faculdade, eu levei a sério, só as matérias que eu gostava, as outras não levava a sério. Eu estudei muito, mas muito, a parte de Introdução à Ciência do Direito, que é uma parte muito filosófica e que te dá a base teórica de todas as matérias do curso de Direito. Se você faz bem isso, você depois com aquela teoria e com um pouco de perspicácia você se vira, sabe? E o código ajudando. Então, eu estudei muito as matérias que eu gostava, na faculdade de Direito, eu levei a sério, estudava muito. As que eu não gostava era na base da embromação mesmo. Eu não colava, mas, porque era uma coisa ridícula na faculdade ficar colando, mas eu embromava, eu tinha uma arte de embromar, mas eu não quero falar mal da faculdade, vamos passar.

\section{E como surgiu a sua relação com as artes, em especial o teatro?}

Mas isso tudo, lá em casa, funcionava. Porque minha mãe, como eu te disse, era para frente. Meu pai tinha uma biblioteca com mais de cinco mil volumes. As irmãs mais velhas, todas estudavam piano, adoravam filme. Eu vou ao cinema com elas desde dois anos de idade, que elas me pegavam e me levavam e eu não chorava, não pedia para sair, ficava de olho grudado, na certa eu não entendia nada, mas estava 
lá. E desde os seis anos eu passei a ir sozinha ao cinema (risos), naquele tempo não tinha perigo, não tinha assalto, e a minha babá me levava, me levava para o cinema, ela dormia e eu assistia ao filme. Ela sentava e imediatamente ela dormia, e eu assistia ao filme. E quando chegava em casa, o papai perguntava: 'o que você viu? Me conte'. Aí eu contava o filme para ele. E papai recitava poesia em casa, tinha um negócio, quando eu via ele recitar poesia, eu chorava, chorava desesperada. Aí papai dizia: 'tira a Maria Sylvia daqui que eu vou ler poesia' (risos).

\section{E a senhora lembra-se de alguma peça, de filmes?}

Olha, eu vi tanto filme, que agora, adulta, quando eu revejo, eu digo: 'mas eu vi esse filme quando eu era muito criança'. Volta, sabe? Eu era muito criança para entender. Outra coisa, nessa época as estantes tinham porta, não eram assim. Então, ele [pai] jamais fechou uma estante, a gente lia o que queria. A mamãe dizia assim: 'mas tu vais deixar essas meninas lerem tudo isso?' Ele dizia: 'se elas entenderem, já estão na idade, se não entenderem, mais tarde elas voltam e entendem'. Então, a gente lia tudo. As minhas irmãs... uma delas era superdotada para desenho, então desenhava, sabe? Em casa sempre teve esse ambiente de apreciar as coisas bonitas.

\section{Além desse convívio com a leitura em sua casa, havia outros espaços em Belém nos quais a senhora frequentava?}

Olha, quando eu estava na faculdade, eu ia muito na casa do Frederico Barata, ele tinha uma coleção de pintura maravilhosa. Ele tinha Picasso, tinha desenhos de mestres famosos, assim. E eu trocava uma festa para ir olhar as coisas lá na casa dele, sabe? Eu gostava muito, e muito mesmo. E cinema, cinema, cinema, cinema, cinema. Lá em casa, a gente nunca apanhou, nenhum beliscão de pai e mãe, o castigo era: 'não vão ao cinema', quando a gente fazia qualquer traquinagem, 'olha, essa semana não tem cinema'. Era horrível para nós, era pior do que sofrer um castigo corporal violento (risos), porque nós amávamos cinema, eu amo até hoje, basta você olhar aqui em torno.

\section{A senhora participou da Turma do Café Central, dessa geração?}

Sim, mas aí eu já estava na faculdade, eu já era grande, como se diz. Essa turma do Central se reunia em torno do Chico Mendes [Francisco Paulo Mendes], que era, assim, um mestre de todos eles, e meu inclusive. E a gente se encontrava lá, e era discutido os livros que iam saindo, e uma exposição de pintura que acontecia, de vez em quando acontecia aqui um salão de pintura efêmero, durava um ano, dois, depois sumia, mas tinha de vez quando uma coisa dessas. Eu lembro. Lembro que o primeiro que eu fui era onde hoje é a Biblioteca Pública, ali onde é o arquivo hoje, ali na [rua] Campos Sales. E eu fui com papai, eu me lembro muito bem que eu fui com ele.

Como ela [Angelita Silva] era uma pessoa mais velha, ela era diferenciada, tanto que ela foi estudar Engenharia, naquele tempo. Só tinham duas mulheres na faculda- 
de, na Escola de Engenharia. E ela era muito ligada com essa coisa de arte visual, ela desenhava também, pintava, fazia demonstração de poesia. Quer dizer, eu sempre vivi no meio assim, sabe? Como eu era caçula, e elas eram três na minha frente, elas me levavam para todo canto, sabe? Então aonde elas iam me levavam junto.

\section{A senhora chegou a participar desses encontros em torno do Francisco Paulo Mendes?}

Ah, sim. Aí eu já era da faculdade, eu ia para lá sempre. Depois que eu comecei a namorar o Bené (Benedito Nunes), então eu ia mais.

\section{O que acontecia nesses encontros?}

Papos. Papos literários, papos de artes plásticas, papos de música, vez por outra acontecia concerto aqui, e a gente ia batendo papo. Também tinha a parte da música popular, mas isso não no Central, mas que a gente cantava muito na faculdade (risos). Música popular tinha tudo isso, tinha de tudo lá.

\section{Na Faculdade de Direito?}

A gente cantava na Praça. A gente ia para a Praça, Mário Faustino, Eu, a gente ia cantar. Era a época daqueles sambas dor de cotovelo, das brigas da Dalva de Oliveira com Herivelto Martins, a gente ia cantar essas coisas. "Abajur Lilás", não sei o quê, (risos), a gente cantava muito.

\section{Então, tinha esse círculo de amizade?}

Olha, coisa melhor da minha vida acadêmica foi o que a gente fazia extra aula. Por exemplo, um descobria um autor, e chegava e dizia: 'olha, estou lendo esse livro aqui', todo mundo: "me empresta, me empresta". O livro circulava. A gente discutia o livro, justamente a gente ia para o Café [Central] discutir o livro, sabe? Conversava, tocava ideia, a gente ia para o cinema todo mundo junto para ver o filme. Eu acho que a gente era um bando de chatinhos (risos).

\section{A Faculdade de Direito, nesse momento, era no centro da cidade, não era?}

Era onde é a $O A B$, agora. Era um prédio velho e as tábuas corridas, muito bonito, ainda é. Tinha um professor nosso que sacudia a perna, a sala inteira sacudia (risos) porque as tábuas eram corridas, era muito engraçado.

\section{E essa tradição da Faculdade de Direito com os artistas ainda é...}

Porque no Brasil a coisa começou sempre com o pessoal do Direito, não é? Se lembra que eles acharam o Bacharel de Cananeia, quando chegaram aqui? E então 
sempre teve essa tradição. E tudo que estava envolvido com arte, estava o pessoal do Direito, no meio.

\section{Que congregavam o que é hoje as Ciências Humanas?}

Exato. Porque não tinham os cursos de Letras, de Filosofia. Não tinha Sociologia, não tinha nada! Era o curso de Direito que fazia essa função. Agora, deixa eu te falar dos colegas, eles são importantes. Tinha o Bené (Benedito Nunes) lá, o Mário Faustino que era um ano atrás da gente. O Haroldo [Maranhão] que era um ano na frente da gente. A Eva Andersen, que era essa minha colega que sempre foi meio geniozinho. A Estela Castro Ribeiro, que era uma mulher maravilhosa, é até hoje. Todos esses colegas eram interessados. Orlando Costa que era muito interessado em cinema, quando eu comecei a namorar ele segurava vela o tempo todo (risos), porque as minhas irmãs estavam todas, duas casadas, e uma [foi] para os Estados Unidos. Aí não tinha como sair só com o namorado, de jeito nenhum. Então, era o Orlando que saía comigo. Pois é, então eram essas pessoas maravilhosas.

\section{As mulheres estavam mais concentradas no curso de Direito do que nas outras áreas?}

Olha, eu acho que éramos mais concentradas, por incrível que pareça, no curso de Medicina, eu acho. Porque eu me lembro que éramos só quatro mulheres numa turma de trinta e quatro homens, e na Faculdade inteira não chegávamos a vinte mulheres. Em Medicina tinha muitas moças estudando. Inclusive eu tinha colegas que muitas foram para Medicina, sabe? Eu acho que era assim, as mulheres estavam conquistando seu espaço, queriam ir logo ao mais difícil (risos).

\section{E a formação em artes não tinha também?}

Não, nenhuma. A gente tinha de se virar. Não tinha televisão, era uma maravilha, não tinha televisão. Então você tinha de usar a cabeça. Tudo o que você lia você tinha que ver com os olhos da cabeça. Você não tinha essa coisa de lhe darem pronto.

\section{E o teatro?}

Ah, o teatro era o seguinte: quando eu era bem pequena, tinha o teatro da Margarida Schivazappa, que era o Tetro do Estudante do Pará. Então, sabe como era teatro de amador, todo mundo fazia enquanto era estudante, quando ficava adulto, ia cuidar da sua vida, ia ser engenheiro, médico, largava o teatro. Então houve uma época que o teatro dela ficou quase sem ninguém. $E$ foi aí que a União Acadêmica resolveu renascer o Teatro dos Estudantes. E a minha irmã, essa mais velha, a Angelita, ela foi chamada para tomar conta dessa parte da União Acadêmica, foi aí que começou tudo. Ela tomava parte desse ramo da União Acadêmica, vamos dizer, ela era a presidente, e a Margarida era a diretora artística. Então eles iam ensaiar lá na 
nossa casa que era enorme, por causa da biblioteca do papai, a gente só podia morar em casa grande. Então eles iam ensaiar lá em casa e eu ficava bicorando, sabe? E ajudando, em tudo o que podia. Eu concertava roupa, eu fazia bainha. Eu nunca me interessei por representar, nunca. Eu gostava era dos bastidores, sabe? Adorava os trabalhos por trás. Mas, assim, para frente, nunca me interessei, é estranho. Porque geralmente os adolescentes adoram se mostrar não é? Mas eu não gostava. Porque eu já tinha tido a minha noite de glória, foi quando eu tinha dois ou três anos, eu era menino Jesus, no Auto que as minhas irmãs faziam no porão de casa, só para família. Então eu era sempre o menino Jesus na manjedoura. Então, esse meu momento de glória já tinha passado. Eu adorava o teatro, fazia tudo, eu fazia todos os trabalhos difíceis, assim, que todo mundo acha chato. Eu fazia. E... mas isso é uma audácia, às vezes penso, quando a gente é jovem tem uma audácia sem par, porque a gente não sabe muita coisa, então é ótimo, porque quando a gente sabe pouco, a gente acha que sabe, eu traduzi uma peça do Bernard Shaw. Eu tinha dezessete anos, olha a audácia, traduzir uma peça de Bernard Shaw, que foi feita [encenada] pela Margarida Schivazappa, agora eu não estou me lembrando o nome da peça.

\section{Era no Poço do falcão?}

Não, o Poço do Falcão era do Yeats.

\section{Esse trabalho era realizado junto ao grupo secundário, nas escolas, não era isso?}

Não. Já era na faculdade.

\section{No Teatro dos Estudantes?}

É. Quase todo mundo já era de faculdade lá, eu acho que todos. Bom, aí eu ficava lá, prestando atenção, decorava todos os papeis, quando alguém não sabia eu soprava. Enfim, eu era assim apaixonada. Mas, continuei estudando as minhas coisas, eu estudava praticamente para agradar meu pai. Ele nunca forçou nada, mas eu sabia que ele ia ficar contente se alguma filha pudesse usar os livros que estavam lá. Eu não tinha vocação para Medicina, muito menos para as ciências exatas, essas, então, praguejei. Então o que me restava? O Direito. Então fui fazer Direito. Foi isso.

\section{A senhora falou da Margarida Schivazappa. A relação dela com o teatro era com esse grupo de Teatro dos Estudantes, e todos esses estudantes eram universitá- rios e não estudantes de escolas?}

Não. Geralmente, eram variáveis, porque se formavam, saíam, e tinha momentos de baixa, e momentos de altas. 


\section{Além da professora Margarida Schivazappa, tinha outras personalidades ligadas ao fazer teatral?}

Tinha o Octávio Cascaes, depois foi Vice-Reitor [da Universidade Federal do Pará]. Ele era muito bom ator, pai da Vera Cascaes. Tinha o Orlando Costa, que foi ministro do Supremo Tribunal do Trabalho, e também trabalhava com a gente. Tinha a Edite Barros que era ótima, mas depois foi ser bancária, tudo assim sabe? Tinha o José Santos, que era irmão do Roberto Santos, que era um ator excelente, que até para os padrões de hoje, quando eu penso, ele era muito bom. E tinha bastante. Tinha um que agora é da Globo, o Lúcio Mauro.

\section{E o que vocês viam de teatro, o que se encenava?}

De vez em quando, aparecia uma companhia itinerante. Eu me lembro que apareceu aqui, mas essa eu quase não fui, eu não sei o que Vianna.... Renato Vianna, que tinha parentes aqui, umas das sobrinhas dele trabalhava com a gente no teatro, Anna Vianna. Eu tenho a impressão que de alguma maneira, para época, ele era uma coisa meio vanguarda.

\section{E que ano era isso?}

Isso é que eu não sei (risos). Aí que está. Tu vais à biblioteca, tu procuras nos jornais que tu vais achar os anúncios das peças.

\section{Mas senhora lembra a década mais ou menos?}

Não sei se 50 ou 40. 50 e 40. Olha, duas décadas, que não são nada, diante da eternidade (risos).

\section{E sobre a criação do Norte Teatro Escola?}

Espera. Ainda teve uma companhia de teatro, que era muito boa, Henriette Morineau trazia gente que depois ficou famosa no teatro como Joacir Campos [Castro], que depois ficou famoso na televisão brasileira, foi pioneiro, fazia um programa com uma câmera só. Tem um outro, Abel Pera, pai da Marília Pera, eu não lembro muito bem, Abel Pera, parece. Rodolfo Arena, uns nomes assim, de gente muito boa. E, antes, ainda, teve uma que era Mário Brasini e Vanda Lacerda, tinha o Osvaldo Louzada, que era excelente.

\section{Essas são as companhias que a cidade recebia?}

É. Nesse tempo, a gente já estava com o Teatro dos Estudantes, da Margarida Schivazappa, e a gente ia assistir, estava lá por dentro, conversava com os atores, e isso era um sucesso medonho. A gente ficava numa excitação enorme, a gente que- 
ria saber uma coisa de cada vez, a gente queria saber mais sobre a profissão, essas coisas.

E sobre a produção que era feita por essas companhias, por exemplo, era essa dramaturgia que a gente chama de dramaturgia universal?

Olha, eu acho que era uma coisa mais assim.... Naquele tempo, a moda era prospecção psicológica, as peças todas tinham o fundo psicológico, e não sei se faziam peças do grande repertório, parece que não. Esse Mário Brasini, inclusive, escrevia as peças, algumas. Ele fazia muita coisa italiana, tradução de peças, vamos dizer, peças comerciais. Certamente na Itália, estavam em voga e eles traduziam e faziam. Esse Renato Vianna, também, fazia peças para teatro. A filha dele, que era a estrela do espetáculo, se chamava Maria Caetana (eu não me lembro), ele anunciava no terceiro ato: "Maria Caetana dançava Tarantela". Era Casa de Bonecas, de Ibsen. Ela era também bailarina.

\section{Então era uma produção muito com o registro de Stanislavski, seria uma coisa assim?}

Eu acho que eles nem se davam a esse luxo.

\section{Porque quando a senhora fala em prospecção psicológica...}

Porque é o seguinte. Logo que o teatro burguês se instalou, nem tinha esse negócio de introspecção. E pouco depois, a história da análise dos comportamentos humanos, a partir de um estudo da "alma", se tornou moda. Então eram tudo peças psicológicas. Veja o teatro de Ibsen, ao lado do realismo, tem uma enorme prospecção filosófica. Só que é disfarçado, quer dizer, disfarçado não, porque era isso que eles faziam, era o realismo, mas no fundo... Pega Strindberg, o próprio Tchekhov, quer dizer, era um teatro que além de tentar caracterizar o meio, a época, etc. e tal, davam ênfase ao homem como pessoa única, não era uma coisa linear, de Tipo. E a partir de um certo momento isso não ficou mais na vanguarda, ficou no teatro comercial. Então, era esse tipo de teatro comercial que eles faziam. Conflitos tremendos, problema homem e mulher, aborto, eutanásia (risos), teses.

Sabes por que eu pergunto isso, porque nos relatórios, a obra do Stanislavski é tipo um diário, olhando é um diário, não é? Ele deixa pistas assim, conceitos como a emoção afetiva, que eu acho que inspira muito a psicologia, por isso a minha pergunta.

Eu acho que, quando essas coisas chegam no Brasil, já passaram por um processo de antropofagia, já foram mastigadas, deglutidas, quer dizer, eles não chegaram puros. A partir da instalação dos grupos de amadores, muito mais tarde, e das escolas de teatro, é que essa coisa começou a ser visto como estudo, metodicamente, 
e a aplicação direta na cena, é mais tardio um pouco. Nesse tempo, eu acho que as pessoas tinham um pouco de intuição também, sabe? Fazer as coisas um pouco pela base da intuição. Eu sempre achei que teatro é uma coisa que não se ensina, a gente ensina as técnicas, mas o teatro é uma coisa da pessoa, assim como qualquer arte, você pode tocar todas as notas do piano e não ser um artista; se tem uma técnica espetacular, mas é frio, não passa nada. Eu acho que sempre se tem essa coisa de intuição. Eu conheço muita gente das artes plásticas que é absolutamente fechada no mundo das artes plásticas, você tenta falar com eles sobre outras coisas, mas não sai nada, é a intuição que empurra eles e que, sei lá, se chama talento, eu não sei o que é, mas é uma coisa assim. Eu acho também que essas pessoas tinham essa espécie de intuição, sabe? Porque uma coisa não surge do nada, então os que faziam teatro estavam sentindo que precisavam fazer outra coisa. Então, intuitivamente, eles passavam teatro para realista, sabe? E afinal de conta, Ibsen aí já tinha não sei quantas décadas de rolar pelo mundo, as peças de Ibsen.

\section{A questão sempre foi o tempo que essas informações chegavam aqui, e a maneira de como chegavam.}

É verdade. Ainda mais aqui no Norte, que era muito separada do resto do Brasil. Por um lado, foi bom, e por outro lado foi péssimo.

\section{Além dessas companhias brasileiras que vinham à Belém, existiam companhias locais que faziam essas apresentações?}

Olha, eu não sei, sinceramente. Porque uma coisa que sempre existiu foi teatro em escola de padre e freira. E era ótimo. Eu me lembro de que, quando eu era bem pequena, eu ia com a minha babá, eu amava! Eu ia ao colégio Santa Rosa. Eu nunca me esqueci de um drama que eu vi lá, que eu chorava tanto. Era um, como é o nome daquele que é apedrejado que vai com a hóstia, ele morre, mas não solta, como é o nome dele? Bom...

\section{Eram esses autos, não é?}

Não. Eram essas coisas que se escrevem para colégios de padre e freira, eu não sei quem escrevia, mas eles faziam. No colégio Nazaré, tinha um palco todo organizado, hoje eu acho que não tem mais, virou uma área enorme, espécie de um palco, espécie de uma área para esportes, não sei o que. Mas tinha um palco e muitos amigos da gente, nessa época, quer dizer, amigos meus não, porque eu era bem pequena, amigos das minhas irmãs, eles trabalhavam nas peças, nós íamos assistir, não perdíamos uma. Era muito engraçado, engraçadíssimo, porque os padres não tinham nenhuma noção da cena, mas era muito bom. Eu me lembro de que tinha um amigo nosso, que era muito engraçado, era muito bom, ele estava perdido na selva, na peça, há uns dez anos, ele se apresentava de cartola, casaca e luvas brancas, perdido na selva dez anos! Tinham outras que eram frequentemente operetas, eles cantavam. Eu 
me dei conta mais tarde que eles faziam operetas, eles cantavam canções e tal. Então, eu me lembro de um, uma vez, ele era pintor, então ele estava pintando e olhando para a plateia com um pincel assim no quadro (risos), e coisas, assim, que nós já notávamos. As minhas irmãs, que eram mais velhas, diziam: "mas que doidice". Elas riam, mas adoravam ir para se divertir, e eu adorava, porque adorava (risos), ficava ali grudada. Eu me lembro do Clodoaldo Beckman, que depois foi diretor da Faculdade de Medicina, e que foi diretor de um monte de coisa na universidade, era uma pessoa ilustre, fazia São José numa peça, no colégio Nazaré, ele era muito magro, quando jogaram ele no poço, os ossos se estralaram (risos). Olha, era muito divertido, a nossa infância era muito divertida.

Então, isso existia, porque eu frequentava. O melhor espetáculo era da obra da Providência, um colégio que tinha na São Jerônimo, de Freiras, que eles faziam o Auto de Natal. Mas era um Auto de Natal que tinha uma superprodução. Tinha cascata em cena. Quando o diabo aparecia, saía chama, cheirava a enxofre. Os anjos desciam do céu. Era superprodução lá nas meninas do Providência. Aí era engraçado, porque as meninas todos de pastores, com bigodes, mas era a única demonstração de que eram homens (risos), porque não apertavam as meninas, elas roliçinhas (risos), era muito bom. Mas, nesse tempo, eu era muito pequena, o máximo até dez anos, porque acabaram com o teatro nas escolas, que é uma pena, não é? Que mesmo assim, capenga, era muito bom, muito bom.

\section{Então tinha muito...}

São Tarcísio, lembrei, o tal santo que era apedrejado. Essa peça eu chorei muito, eu fiquei muito perturbada, eu saí de lá prometendo ser uma menina melhor (risos).

\section{Então, há uma tradição muito forte desse teatro religioso?}

Sim. E também tinha o teatro popular, os Autos mesmo. Mas, nesses eu não tinha com quem ir, porque as minhas irmãs, quando eu estava com idade de gostar disso, elas já estavam adolescentes. Aí elas não queriam mais ir, e eu não tinha com quem ir, mas eu gostava muito. Quando eu tinha oportunidade de aparecer alguém que me levasse, eu ia. Eu ia ver essas coisas que faziam, na própria igreja, sabe? Eu gostava muito.

\section{Isso na sua infância, e depois na sua juventude?}

Aí eu já estava interessadíssima em teatro, eu [era] estudante já. Outra coisa que adoro até hoje, sempre adorei, Pássaro e Boi. Adoro Pássaro e Boi, acho uma coisa tão maravilhosa. E as semelhanças ente o Pássaro e o teatro do século de ouro espanhol é uma coisa, que eu não sei como isso chegou aqui. Se bem que nós já fomos espanhóis, na época do Tratado de Tordesilhas, mas eu não sei como isso chegou aqui, isso dava um grande estudo, não era? Bom, e as peças que o Teatro dos Estudantes, da Margarida Schivazappa, fazia que era um repertório bem melhor, Bernard Shaw, essas coisas assim. 


\section{E onde eram os espaços de ensaio do Teatro dos Estudantes?}

Na casa do meu pai (risos). E depois faziam no Teatro da Paz. Antes que ele começasse a ser fechado, fechado, fechado.

\section{Aí, depois do Teatro dos Estudantes, surgiu o Norte Teatro Escola?}

Mas bem mais tarde. Porque, aí, entrou uma dessas coisas de baixa, baixa maré, todo mundo se formou, foi embora, cuidar da vida. Aí ficou um tempo que não tinha o Teatro do Estudante nenhum, até que Paschoal, que era sempre dono dessas coisas, Paschoal Carlos Magno resolveu fazer um encontro, no Rio de Janeiro, de teatro de amadores. E a Margarida Schivazappa, que já não tinha um grupo instável, foi lá em casa falar para Dadá [Angelita Silva], que era a minha irmã mais velha, essa que cuidava do Teatro dos Estudantes quando ele existiu, porque quando ela se formou foi para os Estados Unidos, todo mundo assim, sabe? Aí, ela foi lá em casa falar com a Dadá: "olha, não podemos perder a oportunidade, porque vai se reunir todos os estados, não sei o que". Aí a Dadá se lembrou que ela tinha ido ao Instituto Brasil Estados Unidos, tinha visto a apresentação da peça $O$ Poço do Falcão, mas foi feita lá, em inglês, fazia parte dos estudos deles. Ela disse: "olha, eu acho que aquela peça seria o ideal para nós, porque só tem quatro personagens, ela é curta", era um Nô, porque o Yeats escreveu vários Nôs, tipo teatro japonês. E aí a minha irmã foi atrás, lá no Instituto Brasil Estados Unidos, aí deram para ela em inglês, aí ela traduziu, e a Margarida Schivazappa juntou o pessoal todo, que eram remanescentes, os que tinham sobrados do Teatro dos Estudantes, Os Novos. E eles foram para o Rio e fizeram a peça, foi um sucesso.

E quando eles voltaram, eu já estava casada, eu comecei a ficar com macaquinhos no sótão, eu disse: "por que a gente não aproveita que teve esse sucesso e.... mas vamos fazer uma coisa diferente, fazer com aula". Porque eu estudava, eu comprava livro de teatro, toda vez que eu ia a São Paulo, eu comprava um monte de livro de história do teatro, disso, daquilo. Eu disse: "a gente estuda direitinho". Aí, nós começamos a nos reunir, aos sábados de tarde, na antiga SAI onde hoje é a Academia Paraense de Letras, e que nessa época era a Sociedade Artística Internacional, que trazia músicos, lá era só música, sabe? Que era um lugar que frequentávamos muito, a minha irmã, a dita cuja irmã era secretária dessa Sociedade, para você ver que eu sempre estive ligada com essas coisas, essas rodinhas. O Augusto Meira Filho era o diretor dessa Sociedade, aí ele nos deixava ir aos sábados para ter aula. Era uma aula assim: "olha, eu li isso, isso, isso", aí quem queria dava palpite também. "Pois eu li isso, isso, isso", era assim muito aberto. A começar a fazer uma peça, e a Margarida também, ela contava as aventuras do passado dela, mas não metia a cara. Eu resolvi: "olha, vamos fazer leitura de poemas?" A gente lia muito poema aqui em casa. "Vamos fazer uma leitura de poemas. Mas, assim, com uma estante, como se fosse recital de música, uma estante, você vai lendo e...". Fizemos com Carlos Miranda, que é uma pessoa importantíssima nesse processo todo. Aí começou, fomos primeiro com Carlos Miranda, foi um sucesso, todo mundo pediu um segundo, fizemos um segundo. 
Deu coragem, fomos fazer uma peça, um auto de Ghelderode, que não tinha mulher, só tinha homem no grupo (risos). A mulher era mais aquela história, será que papai deixa (risos), ou o namorado deixa e tal, então nós só tínhamos homens nesse tempo. Fizemos uma peça só de homens, que era Os Cegos, você conhece essa peça? De um ato, uma peça boa para teatro de escola. Era só homem. Nós fizemos, e eu que dirigi, porque não tinha quem. Eu dirigi assim, doidamente. Aí, também, todo mundo gostou, achou que eu levava jeito, os meninos também gostaram. Nós fizemos outra coisa, ficou aquela animação. As moças começaram a aparecer, as que estavam arredias, começaram a aparecer. Nesse interim, chega Paschoal Carlos Magno aqui dizendo que vai fazer festival de teatro de estudantes e queria que a gente se apresentasse. Nós, nessa época, estávamos estudando, há cinco meses, o Morte e Vida Severina. 0 que era bom de teatro de amador, era isso, não é? Você não tem essa coisa de prazo, e nem tem de cumprir um programa, nada, faz o que dá na telha. Então, nós estávamos todos encantados com o Auto de Natal. Começamos a trabalhar esse Auto de Natal, do João Cabral. E foi tomando corpo, tomando corpo, e a gente foi fazer no tal festival do Paschoal Carlos Magno.

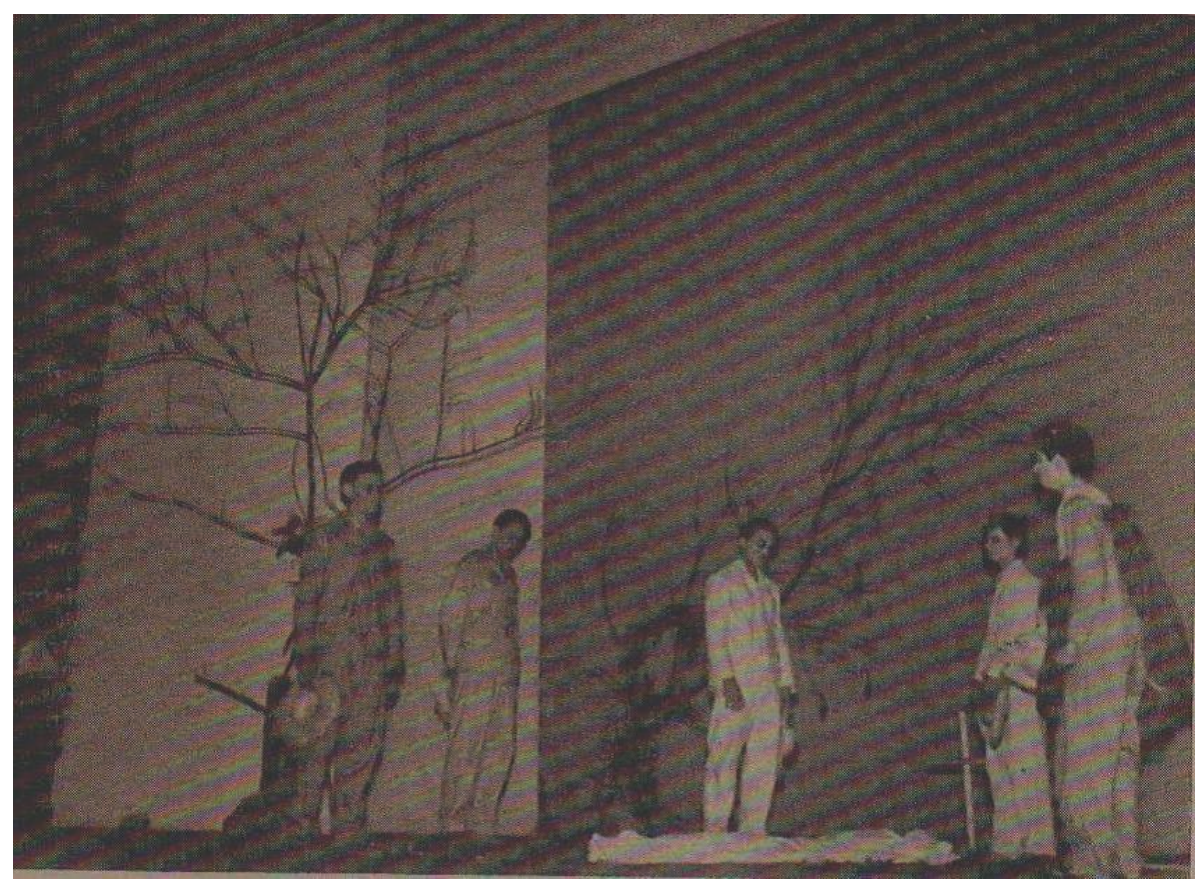

Cena de Morte e Vida Severina, no palco do Derby, Recife 1958. Da direita para esquerda: Carlos Miranda, Paraguassú Éleres, Candido Lemos, Fernando Penna (Peninha) e Wilson Penna (Penão). Fonte: Revista de Teatro da SBAT ${ }^{5}$

Eu escrevi para o João Cabral, pedindo autorização. Escrevi uma carta longuíssima, que eu contava cada cena para ele, como a gente ia fazer, cena por cena. Aí já metemos o Waldemar Henrique para fazer a música. Fomos, assim, chamando os amigos, aquela coisa toda, e afinal fomos até lá fazer. Foi um sucesso. A gente ganhou o primeiro prêmio de peça brasileira, o primeiro prêmio de música de cena, o primeiro prêmio de ator, foi Carlos Miranda que ganhou, só não ganhamos de direção

5 Revista de Teatro da SBAT. Ano XXXVII - Julho - Agosto, 1958 - N 304, p. 21. 
porque o Antônio Abujamra estava concorrendo, aí é covardia, não é? (Risos). E ele já estava até com uma bolsa de estudo para ir para a Itália. Nós pegamos todos esses prêmios, ficamos animadíssimos, voltamos com o ego lá pelos altos. Eu nunca fui de ficar com o ego lá pelos altos, porque eu tenho uma coisa, assim horrível que me atrapalha a vida, eu imagino na minha cabeça uma coisa e a realidade nunca chega lá. Aí eu fico deprimida, porque a realidade não chegou, como eu queria.

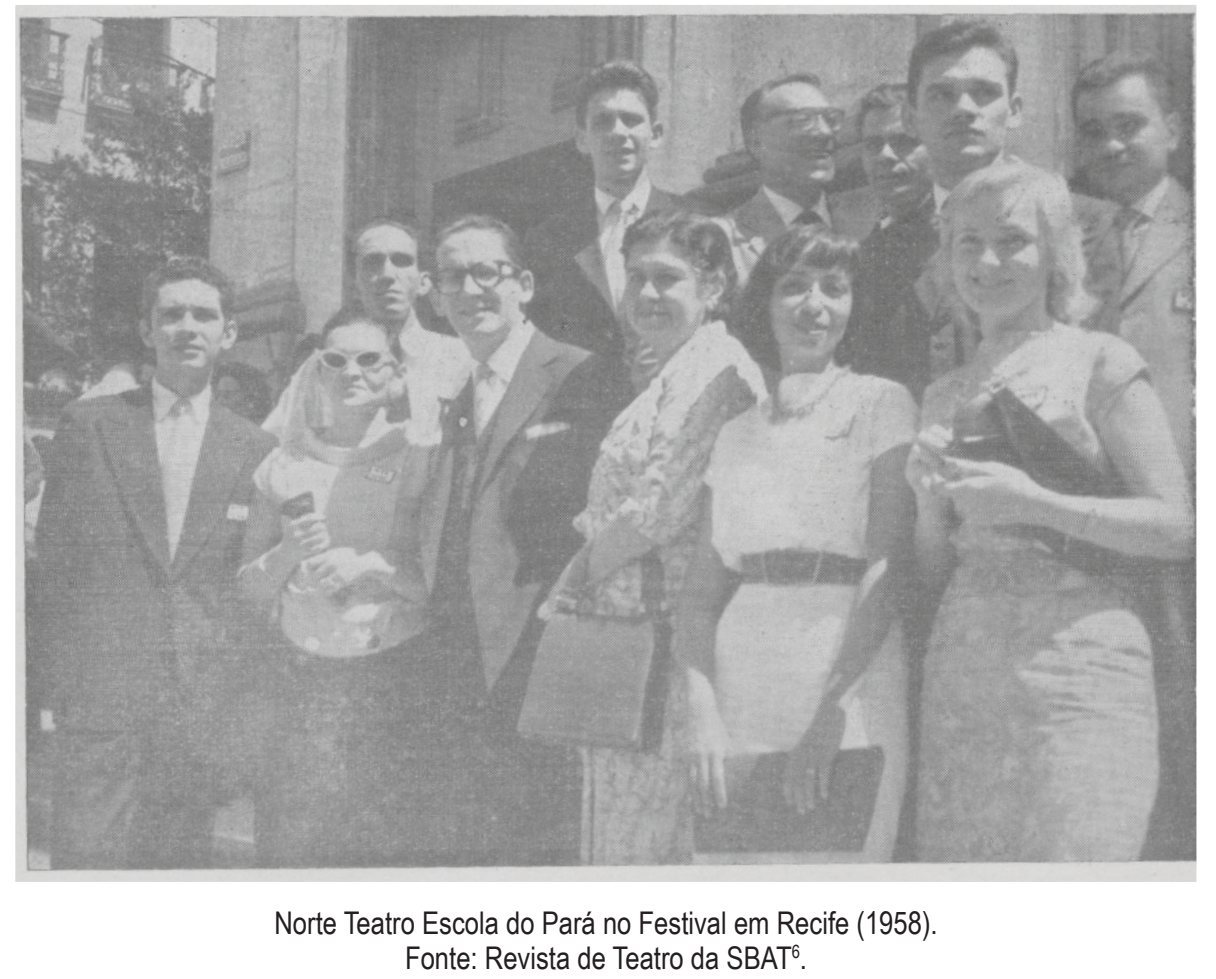

Bom, começamos a pensar qual eram as nossas deficiências, nós não tínhamos as técnicas. As pessoas ficavam cansadas naquele espetáculo, muitas vezes, faltava voz, faltava emissão de voz, faltavam essas coisas. Então fomos pedir para o reitor fazer uma escola de teatro, porque nesse momento o Bené já estava na Universidade lecionando. Por outro lado, o Cláudio Barradas tinha saído do seminário, essas coisas acontecem assim. E estava com um grupo dele, primeiro ele fazia sozinho As Mãos de Eurídice, de Pedro Bloch, ele fez aqui em casa, fazia em vários lugares. Depois, ele começou a juntar esses grupos que funcionavam nas igrejas, nas escolas e fundou uma Confederação. Essa confederação, junto com o Norte Teatro Escola, a gente foi lá com o reitor pedir para fundar uma escola de teatro. O reitor cedeu e nomeou logo o Bené, porque o Bené tinha ido com a gente, ele nomeou logo o Bené, que já era professor da Universidade, e foi assim que começou a escola, desse jeito.

Nós, que já tínhamos relacionamento com muita gente no teatro, muito tempo, nós pegamos os primeiros professores para dar o curso de iniciação, que seria uma espécie de Vestibulinho (risos), o vestibularzinho. Então veio o Amir Haddad, o Carlos Eugênio Marcondes de Moura, Yolanda Amadei, foram só esses três. Um dava dicção, o outro dava expressão corporal, e o outro dava interpretação. O Amir dava interpre- 
tação, o Carlos dicção e a Yolanda expressão corporal. E, assim, começou a escola, simplesmente. A gente tinha uma casa na [Rua] Quintino [Bocaiuva], para dar as aulas e a sede lá. O Bené era o diretor do Serviço de Teatro, eu era a diretora da Escola, e as matérias teóricas era o Bené, o Chico Mendes, era muito legal. Agora, a gente tinha uns Standards lá pelos altos (risos). A gente queria... o ideal nosso era ter uma escola, uma escola russa, você ia de manhã, voltava de noite para casa. Aprender esgrima, aprender balé, aprender luta, esse era o nosso ideal, mas não alcançamos. Mas era assim, nós queríamos as pessoas tecnicamente preparadas para fazer o que quisesse. Bom, aí foi indo à escola aos trancos e barrancos, durante a poderosa Revolução. Isso atrasou muito o desenvolvimento da escola, porque teve aquela época de trevas, mas sobrevivemos.

\section{Voltando um pouco ao Norte Teatro, a senhora falou da obra Morte e Vida Seve- rina, mas quais foram os outros trabalhos que o grupo montou?}

Tem uns os folhetinhos, uns programinhas que a gente fazia. Olha, fizemos lbsen, fizemos os Espectros. Fizemos, deixa eu ver, Édipo Rei. Fizemos Tchekhov, três peças curtas do Tchekhov: O Cisne, Pedido de casamento, e O Urso. Fizemos Martins Penna. Fizemos um bocado de coisa. E depois, quando fizemos a Escola, pronto, o Norte Teatro Escola já tinha cumprido a sua obrigação, acabou.

\section{E onde vocês apresentavam as peças?}

Em vários espaços. A gente apresentava no Pará Club, mas preferivelmente, lá na SAI. Outra coisa, na nossa cabeça nunca passou da gente pedir dinheiro para o governo. Então nós fazíamos tudo com coleta dos amigos. Um negócio, naquele tempo, era que todo mundo era mais pobrezinho que hoje (risos). Então nós inventávamos livro de ouro. A gente mesmo fazia as roupas, eu costurava roupa, roupa, roupa. A gente fazia tudo. Aí, ia dando o jeito que podia.

\section{E a escola não tinha recursos?}

Não, isso era antes da Escola, no Norte Teatro Escola. Na Escola, nesse tempo, era uma maravilha. $O$ doutor Silveira não é muito referido, mas merecia uma estátua na Escola, porque ela dava tudo que a gente queria. A gente chegava lá com o orçamento, e "doutor Silveira, nós precisamos...", vamos dizer que na época era uma quantia grande, vinte mil, e ele, "pois não". Depositava na Caixa Econômica, a gente usava o dinheiro, mas só que tinha que prestar conta com cinco cópias de tudo, mas tudo bem. E outra coisa também, ele comprou uma biblioteca para a Escola, maravilhosa. Nós íamos a São Paulo, comprávamos de milhão de dinheiro na época e ele pagava tudo. Tinha um Cine Clube, que funcionava na Escola. A gente tinha dinheiro a rodo, vocês que pegaram a parte ruim, não é? 


\section{Agora, assim, quem era esse reitor?}

Era o José da Silveira Netto.

\section{Mas qual era profissão dele?}

Médico.

\section{E a senhora tinha alguma relação com ele?}

Não, nunca. Não tinha conhecido ele. Quando ele foi reitor é que a gente foi lá pedir para fazer a Escola. Sabe que ele ia a todos os espetáculos nossos, em tudo. Todo sábado de manhã, tinha o Cine Clube na nossa escola, com 150 lugares, ele ia a todas, impreterivelmente. Peças de passagem de ano, quer dizer, peças montadas lá mesmo, ele ia assistir. Ele era muito interessado. E ele era um homem muito controvertido, as pessoas de outras escolas não gostavam muito dele, de vez em quando tinha atritos entre estudantes e ele, entre UAP e ele, conosco ele era maravilhoso, maravilhoso.

\section{O Norte Teatro participou de quatro festivais brasileiros?}

Não, quatro não. Ele participou do primeiro, em Recife, com Morte e Vida Severina; participou do segundo, com Édipo Rei, foi aí que ele ganhou o primeiro prêmio de direção, primeiro prêmio de ator, um monte de coisa, foi que eu fui para França fazer um estágio lá, nos teatros, foi isso. E o terceiro, em Brasília, com Pic nic no Front, de Arrabal. E o quarto, que foi no Rio Grande do Sul, a gente foi com a peça Biedermann e os Incendiários. Foi isso, quatro.

\section{O de Brasília não?}

Não. Ah, tens razão, foram quatro. Mas o de Brasília não fui eu que fiz, eu já estava na França e o pessoal aqui trabalhando, fez direitinho, muito bacana, o Pic nic no Front. Quando eu cheguei, eu fui só acompanhar o grupo, mas quem dirigiu foi o Penão, e foi tudo bem feito.

\section{Então, a bolsa que a senhora ganhou para ir à França não foi pela encenação de Morte e Vida Severina, mas sim pelo Édipo Rei?}

Édipo Rei, foi com Édipo Rei. Agora quem fez pela primeira vez o Morte e Vida Severina fomos nós, porque o João Cabral quando me respondeu, ele disse que nunca pensou que aquilo pudesse ser feito em cena, porque ele fez, encomendado pela Maria Clara Machado, que tinha o Tablado, e ela mandou dizer que era lindo, que era maravilhoso, mas que nunca se podia botar em cena, foi a resposta que ela deu para ele. Ele acreditou piamente, e quando eu mandei contar para ele, ele disse: "ai que 
bom, porque eu pensei que nunca ia encenar". E ele foi ótimo, mandou o endereço de uns amigos dele em Recife, que nos ajudaram a fazer as coisas, a comprar, achar coisas, inclusive os músicos, eles que nos sugeriram os músicos para apresentação. Foi ótimo.

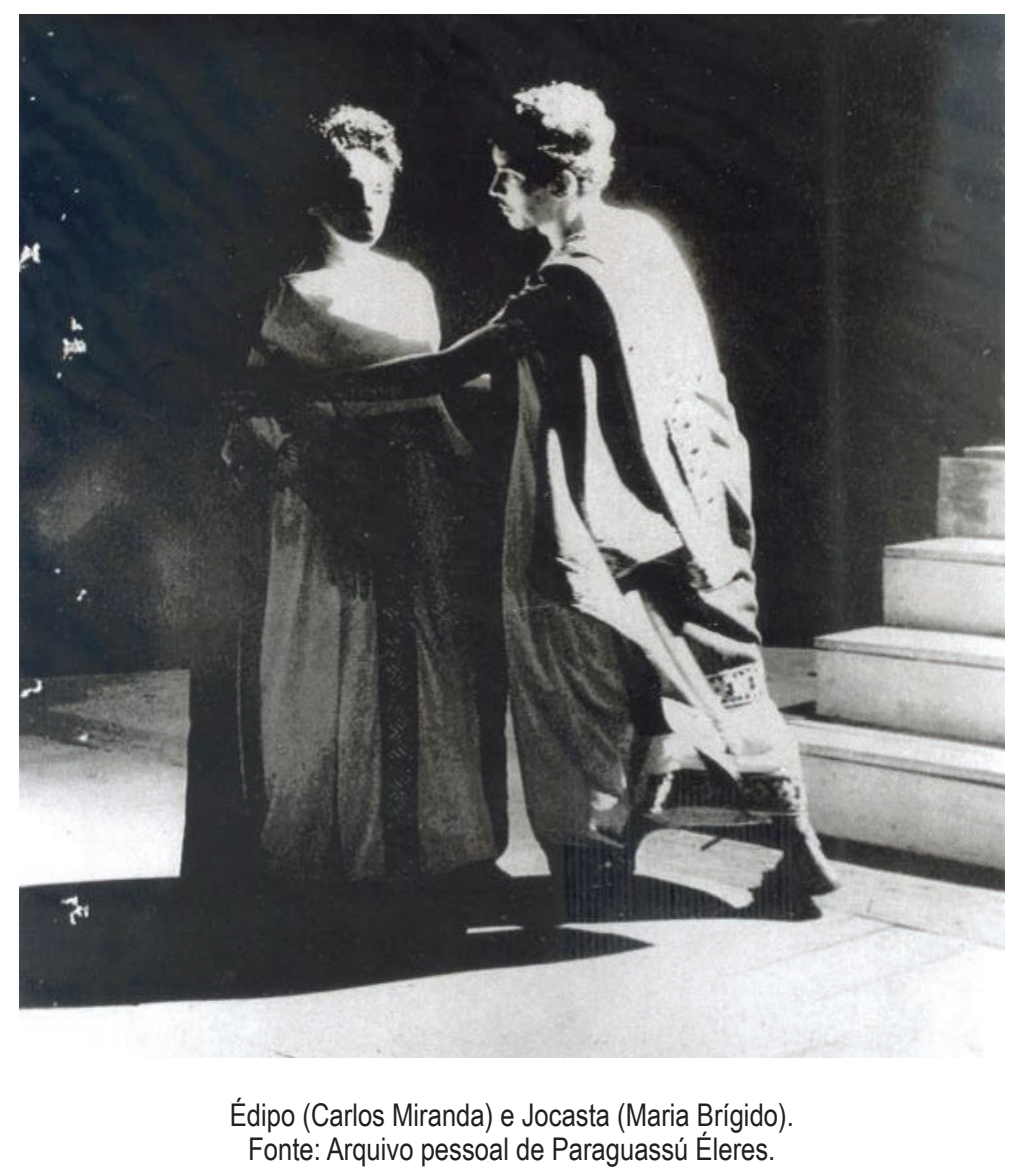

\section{E essa música que o maestro Waldemar Henrique fez para o espetáculo, há regis- tro dela?}

Não. Registro não tem. Mas tem no arquivo dele, no Museu da Imagem e do Som, tem a partitura.

\section{A senhora não lembra da música?}

Se eu quisesse cantar, eu não posso, porque, desde que operei a tireoide, eu perdi a voz, recuperei com muito exercício de fonoaudiologia, mas em compensação eu não posso cantar.

\section{Então ela foi feita para canto também?}

Ela era feita para canto, acompanhada de violão. E era um tema, que o violão tocava sozinho, em certas cenas. Tinha também um Baião, que na cena da "Alegria", quando o menino nasce. O Waldemar fez essa música e foi para Recife com a gente para ajudar lá, achar músicos e foi aí que a gente usou os amigos dele, do João Ca- 
bral, que ficaram amicíssimos nossos, inclusive o Ariano Suassuna, que tinha começado a escrever peças e que nos arranjou os bonequinhos de carnaval, porque aquela cena que ele vem dá os presentes, é tudo bem discriminadinho.

\section{Como diretora do grupo e diretora do espetáculo, como a senhora pensava fazer essa relação entre o texto e a cena?}

Eu parti do texto. Como diz o Bené, nós somos encadernados, a gente era livresco, por princípio. Só que a gente percebia que eram duas linguagens diferentes, o texto é literatura, o texto em cena é teatro, essa é a diferença, uma diferença que Aristóteles já manjava, ele não tinha coragem de falar (risos), se bem que quando ele diz que o Opsis [espetáculo] é a parte menos importante, que ele dava prioridade ao texto, ele dizia isso.

\section{Então vocês priorizavam a literatura, o texto em si?}

Não. Nós priorizávamos botar esse texto em cena. Isso é que era a nossa priorização.

\section{E aí que eu quero the perguntar.}

Diga.

\section{Como é se tornar diretora?}

Não sei. Eu não tenho a menor ideia. Eu meti a cara porque não tinha mais ninguém para fazer. E eu tinha uma turma ótima, e isso ajuda muito. Todos eram apaixonados pelo texto, pelo teatro e tudo. Então, olha, nós ensaiávamos aqui em casa, você vê que o espaço não é tão grande. A gente ensaiava aqui às vezes até 4 horas da madrugada e ninguém ficava cansado, ninguém se aborrecia. Eu ficava, às vezes, aborrecida com o Peninha, dava uns pontapés nele e pronto, acabava.

\section{Eram bons leitores?}

Todos. Todos eram bons leitores e gostavam do que liam, tinham prazer em ler.

\section{E isso ajuda muito.}

Ajuda. E depois uma das minhas decepções na Escola, eram os alunos que chegavam e diz assim: "quais são os livros que você leu ultimamente?" Ficava aquele silêncio na sala, sabe? Quer dizer, eu ainda sou de um tempo que uma cultura geral ajuda a pessoa, muito. Se você tem um dom, claro. 
Porque a geração de hoje é totalmente...

Visual não é? Materialista!

Eu nem sei como the dizer isso, porque eu tenho uma fitha que tem muita informação, maneiras e talentos de lidar com esse universo que está hoje, mas o que eu sinto, de uma maneira geral, dos alunos que chegam, hoje, para estudar, é uma dificuldade de concentração enorme.

Falta o hábito da leitura. A leitura não só te abre mil horizontes, te faz companhia, te ensina, consola, tem todas essas coisas, como ela te dá essa coisa de concentração. Você tira o olho de uma linha, você perde o sentido. Então você se concentra ali. Agora, queres que eu te diga, sinceramente, o que eu acho? Eu acho que tudo vem do curso primário. No meu tempo, no curso primário tinha muitas leituras, perguntas sobre o que a pessoa tinha lido, e durante a aula tinha leitura silenciosa, no meu tempo, o primário era de manhã e de tarde. Quando a gente acabava a leitura, a professora dizia: "agora vocês vão me contar. Fulano, o que tem aí no primeiro parágrafo, conta com as tuas palavras?" A gente ia contando, quer dizer, é uma coisa obrigatória que te dá o hábito, porque é igual a escovar os dentes, ninguém gosta muito, quando criança, mas você insiste, insiste, acaba aprendendo a escovar os dentes. Era isso, a gente acabava aprendendo a ler.

E na Escola de Teatro, vocês davam ênfase nesse processo de formação de leitores também?

Aí já não cabia a nós, eles deveriam chegar sabendo, não é? Só que no Norte Teatro Escola era um pessoal que veio, porque gostava, não tinha título, não ganhava nada, não ia ter coisa nenhuma. Era prazer. O que a gente trabalhava era com enorme prazer.

Era uma troca, como grupo de teatro, grupos de teatro são encontros onde a gente troca o que cada um tem de melhor.

E o que cada um traz, cada um dá o melhor de si.

\section{E na Escola de Teatro?}

Na Escola é diferente, porque tem gente que entra por causa do título, não é?

\section{A Escola também tem a obrigação da formação. E a gente tem de dá essa atenção.}

Também. E outra coisa, do jeito que a Escola está, eu acho muito bem. Eu acho que eles estão de acordo com a realidade. Então essa história de fazer cursos pequenos, isso tem que se fazer na Escola, se não se fizer isso, como é que a Escola vai se 
arrumar? E talvez desses grupos de criança, de adolescente, venham a sair essa formação para o teatro, que ela fala.

\section{E me diga uma coisa, na criação da Escola, como se deu o desenho curricular do curso de teatro?}

Isso a gente tinha muitos amigos na Escola de Arte Dramática de São Paulo. Então nós olhamos o que a gente achava que lá não era bom e o que a gente achava que era bom, e nós todos reunidos fizemos essa coisa. Hoje eu sei que era muito idealizada, mas na época eu achei que era possível.

\section{Então o modelo foi o da Escola de Arte Dramática de São Paulo?}

Sim. Nós pegamos o modelo deles e trabalhamos em cima.

\section{Mas era também uma prospecção de um homem melhor não é?}

Ah, isso era muito importante. Isso era muito importante para nós, porque tenho, talvez eu seja romântica incorrigível, mas eu acho que quando mais a gente sabe, melhor a gente fica, melhor para o mundo, para sociedade, quando mais sabe.

Principalmente para vocês que viveram esse enfrentamento de cultura, dessa transformação social, era necessário um mundo melhor, um homem melhor, porque esse enfrentamento te dá isso, então se acreditou nisso, não é?

Claro. Sabe o que eu acho? Eu acho que aquela Revolução que deu obscuridade na cabeça das crianças, dos adolescentes, ela transformou as pessoas muito em materialistas. As pessoas querem coisas materiais, querem um estudo que te dê uma possibilidade de ter um bom emprego, um bom trabalho e você ganhar bem. São assim muito materialistas, eles querem carro, querem isso. Naquele tempo ninguém tinha carro, a gente andava a pé, todo mundo era pronto e a gente vivia muito feliz.

\section{Mas vocês estavam preocupados com essa questão de uma formação artística?}

Exatamente. A gente estava muito preocupado em saber coisas.

\section{Acreditar que a arte era capaz de transformar o mundo e o homem.}

A gente acreditava nisso. Hoje eu sei que precisa de séculos para que haja transformação (risos). 
E o engraçado, professora, que muitas pessoas acreditam que era uma história da arte pela arte, e nunca teve isso, isso é uma leitura externa não é?

Não. Nunca teve isso. Eu já estou farta de ser classificada de elitista, agora eu já cheguei à conclusão de que é isso. Elitista, se significa você querer coisas melhores, SOU ELITISTA! Agora, se significa classificar as pessoas pelo dinheiro que tem, eu não sou elitista, sabe? É isso que é a beleza pessoal, a preocupação com o corpo. Você vê a quantidade de academia que abriu de repente na cidade, nossa, não tinha uma, só tinha nos clubes (risos).

Na verdade, é quase que um movimento que volta, após a Abolição, que você tinha coisa da boa aparência. Vicente Salles faz muito isso, cataloga os anúncios da fase abolicionista que, de alguma maneira, volta-se a esse valor. É muito estranho, mas é engraçado isso.

Resposta de Maria Sylvia Nunes.

O Norte Teatro é considerado, por alguns e por nós que estudamos teatro paraense, um marco muito importante na história do teatro no Pará, a questão da modernidade, das transformações. A senhora considera isso, e que transformações o grupo fez para cena?

Eu acho que em um momento teve esse papel. E que depois que o Norte Teatro se tornou Escola de Teatro, quer dizer, que teve essa mudança qualitativa, essa metamorfose, eu acho que é a Escola que é importante. Olha, você vê todo mundo que mexe com teatro em Belém, ou já foi da Escola, ou se formou pela Escola, ou passou pela Escola durante um semestre. Enfim, todo mundo que se interessa por teatro passou pela Escola. Você pode ver, não é verdade Karine?

\section{É sim. Uma geração toda.}

Pois é. Eu acho que a Escola é muito importante. Eu fico muito orgulhosa quando eu vou à Escola, quando se tem uma sede, coisa que a gente queria muito. Eles têm uma sede, eles têm um movimento, um teatro funcionando. Podem até ceder para outras pessoas, eu fico muito feliz. Muito feliz.

\section{Mas, em que o Norte Teatro mudou?}

Mudou no sentido de que chegou num momento que não havia teatro de espécie nenhuma sendo feito e ele entrou com textos bons, que a nossa ideia era, se a gente vai ter um trabalho, vamos fazer um trabalho com coisas boas. Não adianta

7 O fragmento a seguir foi cortado pela entrevistada. A entrevista relata nesse trecho sobre o período da ditadura militar, desse contexto na escola de teatro. Afirma que ela e Benedito Nunes resolveram viajar à Europa, como uma forma de "escapar" do que acontecia no momento. Conta ainda sobre a presença de infiltrados do regime militar na escola de teatro. 
pegar um texto vagabundo e ter um trabalho de morte em cima dele. Não. Vamos pegar textos bons, vamos também ver o que está acontecendo de moderno, vamos fazer, vamos criar, como foi o caso do João Cabral, vamos estudar os clássicos, como foi o Édipo Rei, sabe?

\section{Como se abrisse um canal de diálogos com outros universos, com outros mundos que não tinha, não é?}

É. Outra coisa também é aquela história assim, vamos fazer as coisas que o teatro profissional não faz, porque não tem público, porque não é rendoso. Então a gente fez Ghelderode, fez Tchekhov, fez essas coisas que você não vê nem que se você for para o Rio de Janeiro, nem São Paulo. Fizemos Arrabal, a primeira vez fomos nós que fizemos, Pic nic no front, quer dizer, nós fazíamos. Ou a vanguarda, fizemos a Cantora Careca. Fizemos a vanguarda e o clássico. O que a gente queria era que os pontos bons do teatro fossem mostrados, esses pontos bons, essas coisas boas que transformam o mundo, sabe? Quer dizer, a nossa ideia era essa. Deu no que deu.

\section{Inacreditável.}

Pelo tempo, não é?

\section{Eu fico....}

A gente ficou a vida inteira se preparando para ter uma coisa mais "espiritual", melhor, mais conhecimento, mais autoconhecimento, também, mas faz parte de uma evolução. E de repente as coisas dão uma reviravolta.

\section{E vocês viram o centro da intelectualidade brasileira, não é?}

É. Isso é verdade. E de repente as coisas ficam assim, até a música popular, não é? Está num período assim... meio calmaria, uma coisa pontual, uma coisa assim.

\section{Hoje está assim muito difícil.}

Assim, quem tem aspiração de melhorias, menos materialismo, menos consumismo, sente meio fora do esquadro.

\section{Referências}

BEZERRA, José Denis de Oliveira. Vanguardismos e Modernidades: cenas teatrais em Belém do Pará (1941-1968). Belém, 2016. Tese (Doutorado) - Instituto de Filosofia e Ciências Humanas, Universidade Federal do Pará.

Recebido em: 03/08/2019

Aprovado em: 03/08/2019 